\title{
SOURCES OF TAX COMPLIANCE COSTS FOR MALAYSIAN CORPORATE TAXPAYERS
}

\author{
Noor Sharoja Sapiei and Mazni Abdullah
}

\begin{abstract}
Tax compliance costs are the costs incurred by taxpayers in complying with the tax reporting requirements. This study identifies the sources of tax compliance costs for corporate taxpayers with regards to internal and external components. Utilizing a survey of big corporations in Malaysia, the sources of tax compliance costs is investigated. The internal-external costs ratio was 37 per cent and 63 per cent, respectively, indicating that there is a heavy reliance on external sources. This study therefore concluded that tax compliance activities were mainly handled by external tax professionals and not by the internal tax department of the companies. The findings arising from this study provide valuable information on sources of corporate tax compliance costs for policymakers in the area of taxation, and also to the taxation profession in general.
\end{abstract}

Keywords: Tax Compliance Costs, Internal-External Sources, Self-Assessment System (SAS); Corporate Income Tax (CIT); Public Listed Companies (PLCs) JEL Classification: H21, H25, L38

\section{Introduction}

The imposition of taxes by the government results in additional costs to the taxpayers over and above the amount of tax liability that needs to be remitted to the tax authority. These additional costs can be segregated into three broad groupings, namely, administrative costs, efficiency costs and compliance costs.

Administrative costs are the costs incurred by the government in order to administer and collect the taxes (Sandford, 1973). They constitute the costs of operating the tax departments, especially the salaries and wages of the employees, and the assets and equipment necessary to enable the work to be done, as well as the legislative and judicial costs. In contrast, efficiency costs arise because taxes change how people behave. The changes may result in undesirable taxpayers' behaviour, such as fewer savings, less work effort and lower risk-taking than would otherwise be the case (Vaillancourt and Clemens, 2008). Similarly, for the economists, the efficiency costs of taxation are known as 'deadweight losses' or 'excess burden' of a tax to the society (Collard, 1989).

The third category, which is the focus of this paper, is tax compliance costs, which are of particular relevance to income taxpayers. Corporation tax

Corresponding author: Dr Noor Sharoja Sapiei is a Senior Lecturer in the Faculty of Business and Accountancy, University of Malaya, email: noorsharoja@um.edu.my. Dr Mazni Abdullah is a Senior Lecturer in the Faculty of Business and Accountancy, University of Malaya. 
compliance costs refer to the value of resources expended by corporate taxpayers in complying with the tax regulation (Tran-Nam and Glover, 2002). The most frequently cited definition of tax compliance costs is by Sandford (1995a) who defined tax compliance costs as the costs incurred by taxpayers in meeting the requirements laid on them by the tax authorities, over and above the actual payment of tax, which would disappear if the tax was abolished.

Tax compliance requirements for corporations include completing tax returns, maintaining proper records, and obtaining sufficient knowledge to enable these obligations to be accurately executed. Therefore, for corporations, tax compliance costs comprise the cost for collecting, remitting and accounting for tax on the profit of the business, as well as the costs of acquiring the knowledge, such as the information on legal obligations and penalties (Sandford, Godwin and Hardwick, 1989). A summary of the main forms of compliance cost and affected parties is presented in Figure 1.

Ariff and Pope (2002) distinguished the taxation compliance costs into economic and non-economic costs. Non-economic costs are the costs of stress and anxiety caused by tax compliance (psychological costs), which are difficult to quantify. They also identified miscellaneous costs under internal economic costs, which are basically the various other costs incurred in complying with the tax laws (incidental costs). In Malaysia, the introduction of SAS, to replace the OAS, is a major reform of the taxation system since the inception of the ITA in 1967 (Kasipillai, 2005). The new assessment system imposes greater accountability in terms of computational, recordkeeping and filing requirements upon taxpayers. These additional reporting requirements might lead to corporations incurring higher compliance costs.

The objective of this study is to identify the sources (internal and external) of tax compliance costs for corporate taxpayers under the SAS regime. The tax compliance costs burden has been reported in detail for most countries in the advanced economies. However, the literature available from empirical studies conducted in those countries might not provide answers to some of the compliance costs issues in other economies (Ariff and Pope, 2002). The authors asserted that different forces were evident in the emerging economies, such as a large hidden economy, corruption, and inefficiency in tax collection.

Thus, the lack of studies conducted in Malaysia, and in the emerging economies generally, warrants more attention and focus on conducting empirical studies that could provide insights to address some of the issues pertaining to tax compliance costs. In this study, an analysis of tax compliance costs according to the source of income tax work is provided. 


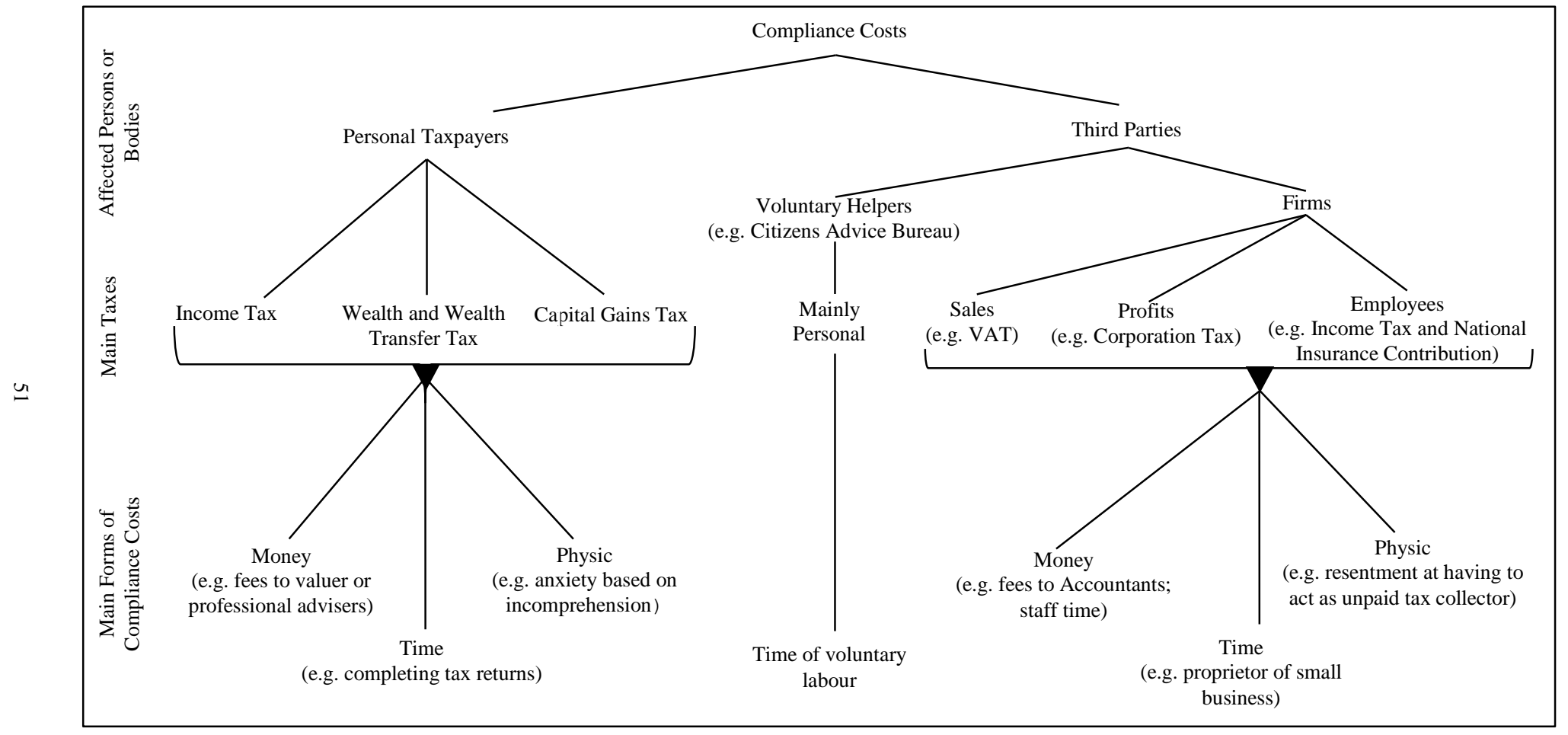

Figure 1: The main forms of compliance cost and affected parties

Source: Sandford, Godwin and Hardwick (1989) 
The rest of this paper is organized as follows. A survey of related literature is provided in Section 2. Section 3 describes the research techniques employed in this paper. The results of the costs analysis by internal-external ratio is reported in Section 4. Section 5 provides comparisons of findings with prior studies and Section 6 concludes this paper.

\section{Literature review}

The knowledge about tax compliance costs has moved from an unknown state to a more familiar position in recent decades. Currently, extensive and varied literature that deals with issues pertaining to compliance costs is available (Evans, 2003). Apart from establishing many of the measurements and conceptual issues in estimating tax compliance costs, these studies have made important contributions in identifying the major elements of tax compliance costs. The issues include allocating costs incurred for accounting or tax compliance costs, computational or tax planning costs, commencement or recurrent costs, as well as differentiating between social compliance costs and taxpayer compliance costs (See for example Pope, 2003).

The literature also covers several types of tax, such as personal income tax (PIT), corporate income tax (CIT), and goods and services tax (GST), as well as different types of taxpayer, including individuals and corporations. This paper focuses on the sources of CIT compliance costs; hence, the review of the literature is related to taxation compliance costs, with a focus on the issues pertinent to corporate taxpayers.

The sources of tax compliance costs can be divided into internal and external cost components (Evans and Tran-Nam, 2001). The internal cost components are based on the time spent by the company staff in handling tax matters and the value of time spent. In addition, some incidental costs might be incurred by corporations in meeting tax compliance requirements. These costs may consist of stationery, forms, postage, telephone bills, utility bills, seminars, travel costs, office space, software maintenance and any other relevant costs. The external sources of income tax work consist of the fees paid to external tax professionals for the tax compliance activities of the company (See for example Tran-Nam, Evans, Walpole and Ritchie, 2000).

The sources of tax compliance cost estimates have been reported in most countries in the advanced economies and some studies in the developing economies. The base papers from which the work started are listed in Table I.

Sandford et al. (1989) found that the compliance costs of UK corporation tax in 1986-87 amounted to $£ 300$ million in aggregate and that half of the compliance costs incurred were fees paid to external tax professionals. Pope, Fayle and Chen (1991) provided compliance cost estimates of Australian PLCs of between AUD646 and AUD1,341 million. Around 91 per cent of PLCs used external advisers and 84 per cent used a combination of internal and external sources. In Canada, a report for the Technical Committee on Business Taxation by Erard (1997) examined the tax compliance costs of Canadian large 
companies for the 1995 tax year. The report indicated average tax compliance costs of CAD507,000 per company and CAD250 million in aggregate, representing approximately 5 per cent of taxes paid.

A seminal study in the US, reported average compliance costs of USD1.57 million per company (Slemrod and Blumenthal, 1996). Approximately 84 per cent of the costs were incurred internally. The analysis of Slemrod and Venkatesh (2002) of large and mid-sized businesses, estimated the compliance costs in the 2001 tax year to be USD254,451 per company. Around 75 per cent of the mean compliance costs comprised internal costs in which the internal compliance activities included 38.8 per cent for pre-filing, 50 per cent for filing and 11.2 per cent for post filing.

Table 1

Sources of tax compliance costs

\begin{tabular}{lcc}
\hline Author(s)(Year); Country & \multicolumn{2}{c}{ Sources (per cent) } \\
\cline { 2 - 3 } & Internal & External \\
\hline Sandford, Godwin and Hardwick (1989); UK & 53 & 47 \\
Pope, Fayle and Chen (1991); Australia & 50 & 50 \\
Ariff, Loh and Talib (1995); Singapore & 42 & 58 \\
Ariff, Ismail and Loh (1997); Singapore & 42 & 58 \\
Slemrod and Blumenthal (1996); US & 84 & 16 \\
Slemrod and Venkatesh (2002); US & 75 & 25 \\
Erard (1997); Canada & 80 & 20 \\
Chan, Cheung, Ariff and Loh (1999); Hong Kong & 30 & 70 \\
Loh, Ariff, Ismail, Shamsher and Ali (1997); Malaysia & 28 & 72 \\
Klun (2004); Croatia & 82 & 18 \\
Blazic (2004); Slovenia & 74 & 26 \\
Hanefah, Ariff and Kasipillai (2001); Malaysia & 75 & 25 \\
Abdul-Jabbar (2009); Malaysia & 59 & 41 \\
\hline
\end{tabular}

The study of Ariff, Loh and Talib (1995) furnished an estimation of the CIT tax compliance costs of PLCs in Singapore for the 1994 year of assessment and found average compliance costs of SGD78,396 per PLC. Only 6 per cent of PLCs used entirely internal staff and 94 per cent used a combination. A similar Singapore estimate, conducted a year later utilizing 1995 data, discovered a significant decrease in tax compliance costs to SGD54,615 per PLC due to simplification of the tax system (Ariff, Ismail and Loh, 1997). Similarly, around 6 per cent used entirely internal staff and 94 per cent used a combination. Comparable findings from a similar study of CIT tax compliance costs in Hong Kong were also reported by Chan et al. (1999). The study, which was administered for fiscal year 1995, observed that a large portion of compliance costs were related to external tax fees (70 per cent).

There is a limited amount of research on tax compliance costs burden in developing countries due to a lack of experts in the area of tax compliance costs, which is exacerbated by a lack of cooperation from the tax authorities (Klun, 2004). Bertolucci (2002) examined the compliance costs of Brazilian listed companies for the 1999 tax year and found that tax compliance costs were BRL7.2 billion in aggregate, representing 0.75 per cent of GDP. Around 80 per 
cent of the costs were internally incurred. The compliance costs of Slovenian companies in 2002 were estimated to be SIT1.5 million per company, 4.2 per cent of tax revenue and 1 per cent of GDP (Klun, 2004). Blazic (2004) found average tax compliance costs of HRK27,113 per company for all Croatian taxes for 2001/02. Internal sources accounted for approximately 74 per cent of the total compliance costs.

Tax studies in Malaysia are very limited, especially concerning estimations of the tax compliance costs. Loh, Ariff, Ismail, Shamsher and Ali (1997), who examined the costs of complying with income tax among PLCs, estimated the average compliance costs to be MYR68,836 per company, which is MYR0.26 per MYR1,000 sales turnover. Around 72 per cent of the costs were paid to external tax advisers. Hanefah, Ariff, and Kasipillai (2001), who estimated the costs of complying with income tax by small and medium enterprises (SMEs), found that the average SME compliance costs were MYR20,703 amounting to approximately 4 per cent of the tax liability. The internal-external compliance costs ratio was 75:25. Abdul-Jabbar (2009), who evaluated the compliance costs estimations for corporate SMEs under the SAS environment, discovered a much lower average of MYR9,295 per company. Around 41 per cent of the costs were paid to external tax advisers.

This study represents the most recent estimation of internal-external sources of tax work. Almost 63 per cent of the total compliance costs were incurred in engaging external tax professionals and only 37 per cent were spent internally in dealing with corporate tax affairs.

\section{Research method}

The sample of companies was drawn from the published directory of the 'Malaysian Top 500 Largest Listed Corporations 2008-2009'. Companies in Eastern Malaysia, namely Sabah and Sarawak, and sectors with fewer companies were excluded from the main sample due to budgetary and time constraints.

The development of research instruments for this study comprise two sequential steps involving questionnaire design and pre-testing. The instruments were pre-tested on a group of academics and practitioners to ensure that the questionnaires were both clear and understandable. In this study, the measurement of tax compliance costs estimate applied most of the techniques employed by established researchers who have carried out studies in this field (for example Sandford et al., 1989) (Table 2). 
Table 2

Cost computations and questionnaire items

\begin{tabular}{|c|c|c|}
\hline Source & Cost Computations & Questionnaire Items \\
\hline $\begin{array}{l}\text { Internal } \\
\text { Costs }\end{array}$ & $\begin{array}{l}\text { Computed by multiplying annual time } \\
\text { spent on tax activities to their } \\
\text { respective hourly wage rate. Include } \\
\text { incidental compliance costs incurred. }\end{array}$ & $\begin{array}{l}\text { Internal costs of complying with the } \\
\text { income tax law relating to company: } \\
\text { - Time spent by staff in handling tax } \\
\text { activities } \\
\text { - Incidental costs and nature of } \\
\text { expenses } \\
\text { - Percentage of computational and } \\
\text { planning costs }\end{array}$ \\
\hline $\begin{array}{l}\text { External } \\
\text { Costs }\end{array}$ & $\begin{array}{l}\text { Money cost charged by external tax } \\
\text { professionals solely on tax activities }\end{array}$ & $\begin{array}{l}\text { External costs of complying with the } \\
\text { income tax law relating to company: } \\
\text { - } \quad \text { Engage external tax professional - } \\
\text { Yes/No } \\
\text { - External tax fees } \\
\text { - Percentage of computational and } \\
\text { planning costs }\end{array}$ \\
\hline
\end{tabular}

The estimation of internal staff costs was based on the time spent by a company's internal staff in handling tax matters and the value of time spent. The cost was estimated using a mathematical formula adapted from the study by Evans, Ritchie, Tran-Nam and Walpole (1997). Concerning the internal staff time, the survey respondents were requested to provide the number of staff who handled tax matters in their company and an estimation of the time spent entirely on income tax purposes. Similar to the study by Evans et al. (1997), a standard wage rate approach was utilized in this study to value the internal time spent. External tax fees are payments made to acquire services of external tax professionals on tax related matters from outside the company. The method employed by earlier relevant studies was through requesting from the respondents the tax fees incurred by their company for the corporate income activities in the respective tax year.

The data collection for this study utilized a researcher-administered questionnaire survey method. Estimation of tax compliance costs has generally relied on self-reports using a postal survey (Evans, 2003), which raises the question of accuracy and reliability. In addition, a survey using postal questionnaires would likely result in a low response rate (Sandford, 1995b). A researcher-administered survey method can address these shortcomings, as, according to Hanefah et al. (2001), a representative population using personal data collection, will yield a higher response rate, as well as result in more reliable responses. By utilizing this method, questionnaires can be personally distributed, which provides the opportunity for researchers to emphasize verbally the importance of the study as well as appreciation for the collaboration of the individuals.

In most cases, the potential respondents of each firm were contacted by telephone to outline the purpose of the survey, to confirm whether the firm satisfied the selection guidelines, and to ascertain the person's willingness to participate in this study. 
Prior to the meeting, a covering letter and explanatory statements specifying the purpose of the research and assuring anonymity of the respondent, as well as the questionnaire, were e-mailed to respondents. This was to prepare them for the survey and to establish the authenticity of the person meeting the respondents (Hanefah et al., 2001). The target respondents were the CFO or tax director of PLCs in Malaysia. This was deemed acceptable as these groups possess significant work experience and appropriate professional qualifications, which would enable them to provide reasonable information for the purposes of this study. An overall response rate of 20.7 per cent was obtained, and it was conducted on a fairly representative population of PLCs albeit quite a large number of companies were not able to respond due to time constraints. The respondents involved in this study were mainly finance and tax managers.

The highest response was gathered from the services sector (33.7 per cent), followed by the manufacturing (31.6 per cent) and the property and construction (21.4 per cent) sectors. As for the size of business, the highest response was from the companies with annual sales turnover level of between MYR100 and MYR500 million (36.7 per cent); followed by the annual sales turnover level of less than MYR100 million (31.6 per cent). The majority of responding companies (55.1 per cent) had been in operation for at least 15 years and 23.5 per cent had been in operation for more than 30 years, which signified that the sample respondent companies had adequate experience in dealing with tax related issues. Nearly one-half of the companies (48 per cent) estimated their tax liability to be less than MYR5 million and the remaining percentage fell in the category of MYR5 million or more ( 42.8 per cent).

With respect to the sources of income tax work, some companies handled their tax affairs internally, some completely outsourced their tax-related activities and a large proportion of corporate taxpayers made use of both sources (Table 3). Almost 95 per cent of the respondent companies employed external tax professionals and more than 70 per cent utilized both internal resources and external tax professionals to deal with their income tax matters. Twenty-four (24) companies completely outsourced their tax-related activities and only five companies were totally dependent on their internal tax expertise.

Table 3

Sources of income tax work

\begin{tabular}{|c|c|c|}
\hline Sources & Number of companies & Percentage \\
\hline Internal only & 5 & 5.1 \\
\hline External only & 24 & 24.5 \\
\hline Internal and External & 69 & 70.4 \\
\hline
\end{tabular}




\section{Costs analysis by internal-external ratio}

This section examines the tax compliance costs in terms of sources of costs (internal-external ratio).

The internal-external ratio is derived by dividing the means of internal and external compliance costs, respectively (Johnston, 1963). Adapting the approach of similar previous studies, incidental costs were included under the internal costs component. In this study, the internal-external compliance costs ratio was 37:63, indicating that tax compliance activities were mainly handled by external tax professionals. The internal-external costs ratio was further analysed by the characteristics of the PLCs; namely, sales turnover, business sector and length of business operation.

The internal-external compliance costs ratio, which were analysed by turnover level, indicated a heavy reliance on external tax professionals for PLCs in the lowest and highest levels (Table 4). Companies in the middle range of sales turnover, between MYR100 and MYR500 million, seemed to have an almost equal proportion of dependence on internal staff (52 per cent) and external tax professionals (48 per cent). However, an ANOVA test did not reveal any significant mean differences of internal-external compliance costs ratio by sales turnover.

Table 4

Internal-external compliance costs ratio by sales turnover

\begin{tabular}{lccc}
\hline Turnover Level (Million) & & \multicolumn{2}{c}{ Compliance Costs Ratio (per cent) } \\
\cline { 3 - 4 } & & Internal & External \\
\hline Less than MYR100 & $(31)$ & 29 & 71 \\
MYR100 - MYR500 & $(36)$ & 52 & 48 \\
More than MYR500 & $(31)$ & 29 & 71 \\
Overall & $(98)$ & 37 & 63 \\
\hline
\end{tabular}

${ }^{a}$ Number of respondents is given in parentheses

The findings of the internal-external compliance costs ratio by business sector are presented in Table 5. These findings show that the construction sector was highly dependent on external tax professionals to handle the company's tax matters (83 per cent). As suggested by Abdul-Jabbar (2009), this may perhaps be due to the differences in the accounting practices of the construction sector, especially in terms of the revenue-recognition. To a lesser degree, the technology ( 78 per cent), services (61 per cent) and manufacturing (60 per cent) sectors also depended more heavily on external sources. In contrast, the finance and banking (49 per cent) sector, along with the plantation and agriculture (42 per cent) sector, had a lower reliance on external sources, with these companies more inclined to entrust tax matters to their internal staff. However, the ANOVA test did not find any significant mean differences of internal-external compliance costs ratio by business sector. 
Table 5

Internal-external compliance costs ratio by business sector

\begin{tabular}{lrcc}
\hline Business Sector $^{\text {a }}$ & & \multicolumn{2}{c}{ Compliance Costs Ratio (per cent) } \\
\cline { 3 - 4 } & & Internal & External \\
\hline Manufacturing & $(31)$ & 39 & 61 \\
Services & $(33)$ & 38 & 62 \\
Property and Construction & $(21)$ & 17 & 83 \\
Finance and banking & $(6)$ & 51 & 49 \\
Plantation and agriculture & $(6)$ & 58 & 42 \\
Technology & $(1)$ & 22 & 78 \\
Overall & $(98)$ & 37 & 63 \\
\hline
\end{tabular}

${ }^{\mathrm{a}}$ Number of respondents is given in parentheses

With regards to length of business operation, the internal-external compliance costs ratio increased with the length of time that a business had been operating (Table 6). The longer the PLCs had been in business, the higher the internalexternal compliance costs ratio, suggesting a greater reliance on internal sources. Similar to the earlier findings of sales turnover level and business sector, the ANOVA tests suggested no statistical mean differences for length of business operation.

Table 6

Internal-external compliance costs ratio by length of business operation

\begin{tabular}{llcc}
\hline Length of Business Operation $^{\text {a }}$ & & \multicolumn{2}{c}{ Compliance Costs Ratio (per cent) } \\
\cline { 3 - 4 } & & 29 & Internal \\
\hline Less than 15 years & $(21)$ & 35 & 71 \\
15 to 30 years & $(54)$ & 48 & 65 \\
More than 30 years & $(23)$ & 37 & 52 \\
Overall & $(98)$ & & 63 \\
\hline
\end{tabular}

${ }^{\mathrm{a}}$ Number of respondents is given in parentheses

\section{Comparison of findings with prior studies}

The findings on the sources of costs in terms of internal-external costs ratio showed a 9 per cent increase in the proportion of internal sources of costs compared to the earlier study on PLCs by Loh et al. (1997). The findings of this study, however, did not support those of Abdul-Jabbar's (2009) study on SMEs, which found a 16 per cent decrease in the proportion of internal work under the SAS. He argued that the increase demonstrated that tax professionals played a more significant role in the SAS regime.

This contradictory result may be due to the variation in the groups of respondents employed in each study. This study focused on PLCs, where an increase in the proportion of internal sources of costs may not indicate that external tax professionals were no longer playing a significant role in the SAS regime. Instead, it might demonstrate that more companies were taking tax issues seriously by having their own tax department handle tax affairs. The possibility of companies establishing facilities and expertise to handle their tax activities internally due to the additional compliance requirements under SAS, is another possible explanation for the increase in reliance on internal sources. 
Internationally, the Malaysian internal-external costs ratio scored lower than countries in the advanced economies. One possibility is because Malaysia is yet to establish expertise in handling corporate tax activities internally. Hence, it might be more economical for companies to outsource their tax work compared to managing their own tax departments.

\section{Conclusion}

This paper examines CIT compliance costs in terms of sources of costs (internal and external) for the Malaysian PLCs. Specifically, the study's research objective is stated as follows: "To assess the sources of tax compliance costs incurred by Malaysian corporate taxpayers under the self-assessment system (SAS)".

With regards to the internal-external sources of tax work, 63 per cent of the total compliance costs were incurred in engaging external tax professionals to deal with the company tax affairs. This suggests a greater reliance on external sources, in handling corporate tax matters, such as preparing tax returns and for purposes of tax documentation.

The components of the internal and external sources as a percentage of annual sales turnover were U-shaped, implying that the PLCs in the lowest and highest size levels utilised greater external resources compared to medium-sized companies. The medium-sized PLCs, with an annual sales turnover value of between MYR100 and MYR500 million, did not show much difference between the internal-external sources of tax work.

This study contributes to the body of knowledge, especially when one takes into consideration the very limited tax studies in emerging economies. The overall conclusions that can be drawn from this study's research findings are broadly in line with existing studies in these areas. Thus, the findings of this study add to the research evidence from countries in emerging economies, which, according to Ariff and Pope (2002), have a weaker tax policy and structure, and a less transparent tax system than those in the advanced economies. In addition, this study also meets the call made by Evans (2003), in seeking more evidence from countries in emerging economies on the corporate taxpayers' compliance costs burden.

Practically, this study contributes to the aim of providing information in order that policy decisions may be based on reliable data through research findings. Thus, the findings of this study provide important elements for future tax policy decision-making in Malaysia and in the emerging economies generally, where tax studies are very limited. Future studies should explore the feasibility of replicating or extending this study in other tax jurisdictions, perhaps through collaboration with researchers of the respective countries. 


\section{References}

Abdul-Jabbar, H. (2009). Income tax non-compliance of small and medium enterprises in Malaysia: Determinants and tax compliance costs. Unpublished doctoral dissertation, Curtin University of Technology, Perth, Australia.

Ariff, M., Ismail, Z. and Loh, A. (1997). Compliance Cost of Corporate Income Taxation in Singapore. Journal of Business, Finance and Accounting, 24(9/10): 1253-1268.

Ariff, M., Loh, A. and Talib, A. (1995). Compliance Cost of Corporate Taxation in Singapore. Accounting Research Journal, 8: 75-87.

Ariff, M. and Pope, J. (2002). Taxation and Compliance Cost in Asia Pacific Economies. Sintok: University Utara Malaysia Press.

Bertolucci, A. (2002). The compliance costs of taxation in Brazil: A survey of costs in Brazilian public companies. Unpublished doctoral dissertation, University of Sao Paulo, Brazil.

Blazic, H. (2004). Tax compliance costs of companies in Croatia. Ekonomickỳ časopis, 6: 723-38.

Chan, S.Y.S., Cheung, D.K.C., Ariff, M. and Loh A.L.C. (1999). Compliance Costs of Corporate Taxation in Hong Kong. The International Tax Journal, 24(4), 42-68.

Collard, D. (1989). Compliance costs and efficiency. In C. Sandford, M. Godwin and P.Hardwick (Eds.), Administrative and compliance costs of taxation (pp. 273-277). Bath, UK: Fiscal Publications.

Erard, B. (1997). The income Tax Compliance Burden on Canadian Big Business (Working Paper 97-2). Ottawa, Canada: Technical Committee on Business taxation, Department of Finance.

Evans, C. (2003). Studying The Studies: An Overview of Recent Research into Taxation Operating Costs. eJournal of Tax Research, 1(1): 64-92.

Evans, C., Ritchie, K., Tran-Nam, B. and Walpole, M. (1997). A Report into Taxpayer Costs of Compliance. Canberra: Australian Government Publishing Service.

Evans, C. and Tran-Nam, B. (2001, July). The Compliance and Administrative Costs of the TVM: What are the Implications? Paper presented at the Tax Value Method Consultative Conference organised by ATAX for the Board of Taxation, Crowne Plaza Coogee Beach, Australia.

Hanefah, M., Ariff, M. and Kasipillai, J. (2001). Compliance Costs of Small and Medium Enterprises. Journal of Australian Taxation, 4(1): 73-97.

Johnston, K.S. (1963). Corporations' federal income tax compliance costs: A study of small, medium-size, and large corporations (Monograph 110). Ohio State University, Columbus: Bureau of Business Research, College of Commerce and Administration.

Klun, M. (2004). Taxation Compliance Costs for Companies in Slovenia. Economic and Business Review for Central and South- Eastern Europe, 6(4): 325-336. 
Loh, A., Ariff, M., Ismail, Z., Shamsher, M. and Ali, M. (1997). Compliance Costs of Corporate Income Taxation in Malaysia. Pacific Accounting Review, 9(1): 27-42.

Pope, J. (2003). Research Methodology for Estimating the Compliance Costs of the Goods and Services Tax in Australia. In A. Lymer and D. Salter (Eds.), Contemporary issues in taxation research (pp. 69-86). Aldershot: Algate Publishing.

Pope, J., Fayle, R. and Chen, D.L. (1991). The compliance costs of public companies' income taxation in Australia, 1986/87 (Research Study No. 13). Sydney, Australia: Australian Tax Research Foundation.

Sandford, C. (1973). Hidden cost of taxation. London: Institute for Fiscal Studies.

Sandford, C. (1995a). The Rise and Rise of Tax Compliance Costs. In C. Sandford (Ed.), Tax Compliance Costs Measurement and Policy. The Institute for Fiscal Studies, Bath, UK: Fiscal Publications.

Sandford, C. (1995b). Improving the Methodologies. In C. Sandford (Ed.), Tax Compliance Costs Measurement and Policy. The Institute for Fiscal Studies, Bath, UK: Fiscal Publications.

Sandford, C., Godwin, M. and Hardwick, P. (1989). Administration and Compliance Costs of Taxation. Bath, UK: Fiscal Publications.

Slemrod, J. and Blumenthal, M. (1996). The Income Tax Compliance of Big Business. Public Finance Review, 24(4): 411-438.

Slemrod, J. and Venkatesh, V. (2002). The Income Tax Compliance Cost of Large and Mid-Size Businesses (A report to the IRS LMSB Division). University of Michigan Business School: Office of Tax Policy Research.

Tran-Nam, B., Evans, C., Walpole, M. and Ritchie, K. (2000). Tax Compliance Costs: Research Methodology and Empirical Evidence from Australia. National Tax Journal, 53(2): 229-252.

Tran-Nam, B. and Glover, J. (2002). Tax Reform in Australia: Impacts of Tax Compliance Costs On Small Business. Journal of Australian Taxation, 5(3): 338-381.

Vaillancourt, F. and Clemens, J. (2008). Compliance and Administrative Costs of Taxation in Canada. In J. Clemens (Ed.), The impact and costs of taxation in Canada: The case for flat tax reform (pp. 55-102). Canada: The Fraser Institute. 